\title{
PEMBUATAN KAPAL NELAYAN FIBERGLASS KOTA PADANG DENGAN METODE HAND LAY UP
}

\author{
SANNY ARDHY ${ }^{1}$, MEIKI ERU PUTRA ${ }^{2}$, ISLAHUDDIN $^{3}$ \\ Dosen Teknik Mesin, Universitas Dharma Andalas, Padang ${ }^{1,2,3}$ \\ sannyardhy@gmail.com¹, meikieruputra@gmail.com ${ }^{2}$, islahuddin@unidha.ac.id ${ }^{3}$
}

\begin{abstract}
Wooden fishing boats gradually began to be abandoned by fishermen. Now, many fishermen have switched to using ships from materials fiberglass. This is because the amount of wood that has been increasingly limited, and the price is also very expensive. In addition, wooden ships require a lot once treatment and lifespan are also limited. While the advantages of fiberglass boats, among others, age or lifetime of the ship more durable, maintenance is much easier and cost-effective (cost). Fiber ships are also much lighter, and more leverage in the production of fish catch. Fiberglass shipbuilding process that many made, using Fiberglass Reinforced Plastic (FRP) technique. In the manufacture of fiber boats, there are two frequently used lamination methods, namely Hand Lay Up and Chopper Gun. This method is the easiest and simplest method of lamination. Hand Lay Up is an open mold method. This method is carried out by applying resin to the reinforcing material using brush/roll. The research was conducted in Muaro Beach fishing area Padang. There are five units of fiberglass fishing vessels that are sampled. The purpose of this research is to assist fishermen, especially producing ships fiberglass is much better to maximize the catch of fish.
\end{abstract}

Keywords : FRP, hand lay up, resin, open mould, Pantai Muaro

Abstrak: Kapal nelayan dari bahan kayu lambat laun sudah mulai ditinggalkan oleh nelayan. Kini, nelayan sudah banyak beralih menggunakan kapal dari material fiberglass. Ini dikarenakan jumlah bahan kayu yang sudah semakin terbatas, dan harganya juga sangat mahal. Selain itu, kapal kayu membutuhkan banyak sekali perawatan dan masa pakainya juga terbatas. Sementara kelebihan kapal fiberglass antara lain, usia atau masa pakai kapal lebih tahan lama, perawatan jauh lebih mudah dan hemat biaya (cost). Kapal fiber juga jauh lebih ringan, dan lebih maksimal dalam produksi tangkap ikan. Proses pembuatan kapal fiberglass yang banyak dibuat, menggunakan teknik Fiberglass Reinforced Plastic (FRP). Dalam pembuatan kapal fiber, ada dua metode laminasi yang sering digunakan, yakni Hand Lay Up dan Chopper Gun. Metode ini adalah metode laminasi yang paling mudah dan sederhana. Hand Lay Up adalah metode cetakan terbuka (open mould). Metode ini dilakukan dengan cara mengaplikasikan resin pada bahan penguat dengan menggunakan kuas/rol. Penelitian dilakukan di daerah nelayan Pantai Muaro Padang. Ada lima unit kapal nelayan fiberglass yang menjadi sampel. Tujuan penelitian ini untuk membantu nelayan, khususnya memproduksi kapal fiberglass yang jauh lebih baik untuk memaksimalkan hasil tangkapan ikan.

Kata Kunci : FRP, hand lay up, resin, open mould, Pantai Muaro

\section{PENDAHULUAN}

Kota Padang adalah ibukota provinsi Sumbar yang terletak di pesisir pantai barat pulau Sumatera, dengan garis pantai sepanjang $84 \mathrm{~km}$. Hampir sepertiga penduduk Kota Padang yang berjumlah 900.000 jiwa, menggantungkan hidupnya sebagai nelayan. Kapal nelayan di Kota Padang, umumnya terbuat dari kayu. Seperti diketahui, kapal kayu dan fiberglass memiliki berat yang berbeda yaitu $20 \mathrm{Kg} / \mathrm{m} 2$ untuk kayu dan $14 \mathrm{Kg} / \mathrm{m} 2$ untuk fiberglass. Faktor berat ini sangat mempengaruhi displacement dan stabilitas kapal, tentunya juga terhadap hasil tangkap. Selain itu, yang menjadi permasalahan yakni jika terjadi kelangkaan kayu. Karenanya, penggunaan fiberglass diharapkan dapat mengganti kayu sebagai material utama pembuat kapal, terutama untuk kapal nelayan berukuran kecil dan menengah. Pada umumnya, pembuatan kapal nelayan memakai kayu yang sangat berkualitas, seperti kayu jati yang sudah tua. Akan tetapi, sekarang kayu jati pun sudah mulai langka. Jikapun ada, harganya pun sangat mahal. Ini semua menyebabkan nelayan merasa kesulitan dalam membuat 
kapal. Oleh sebab itu, kini nelayan mulai berpikir untuk beralih ke fiberglass sebagai bahan dasar pembuat kapal. Di samping ketersediaannya cukup, harganya pun tak mahal dibanding kayu. Tak hanya itu, hasil tangkap ikannya pun jauh lebih banyak. Karena kapal fiberglass jauh lebih ringan, lebih fleksibel dalam menangkap ikan. Tujuan penelitian ini untuk nelayan dan Pemko Padang. Khusus untuk nelayan, penelitian ini bertujuan membantu nelayan untuk meningkatkan produktivitas hasil tangkapan nelayan dan kesejahteraan nelayan. Sementara untuk pemda, penelitian ini dapat digunakan sebagai referensi dalam penyusunan Anggaran Pendapatan Belanja Daerah (APBD) untuk membantu pengadaan kapal fiberglass bagi nelayan. Adapun manfaat penelitian ini untuk meningkatkan pertumbuhan ekonomi sektor riil masyarakat Kota Padang, khususnya di bidang kelautan (maritim). Adapun batasan masalah penelitian ini yakni proses teknik pembuatan kapal fiberglass menggunakan metode Hand Lay Up. Teknologi perancangan membahas tahap perancangan, pemilihan bahan, dan penentuan kriteria dasar perancangan seperti koefisien pembagian/penggunaan ruang, faktor kenyamanan (safety) dan penampilan (performance).

\section{Potensi Maritim Kota Padang}

Kota Padang merupakan kota yang paling berkembang dibanding kota-kota lainnya yang terletak di kawasan perairan tepi barat Pulau Sumatera. Kota ini berbatas langsung dengan Samudera Indonesia. Kota Padang berkembang seiring posisi strategisnya, sehingga sejak lama telah menjadi salah satu pelabuhan di kawasan tepi barat Sumatera, di samping kedudukannya sebagai ibukota provinsi. Dengan posisi demikian, banyak usaha-usaha kelautan yang mempunyai potensi untuk berkembang, khususnya usaha kelautan dan perikanan. Di Kota Padang, selain di Pantai Muaro, kapal nelayan juga banyak beroperasi di Pasia Nan Tigo, Air Tawar, Purus, Gauang, Bungus dan Sungai Pisang. Potensi pengembangan industri kemaritiman di Sumbar cukup besar karena luas laut mencapai 186.580 kilometer persegi atau 81 persen dari total wilayah yang ada. Dengan panjang garis pantai 1,973,2 kilometer dan berada di lokasi strategis di Samudra Hindia, potensi ikan tersedia sepanjang tahun. Potensi perikanan yang ada juga telah menjadi komoditas ekspor ke sejumlah negara tujuan seperti Jepang, Tiongkok, Korea, Hongkong, Afrika dan Timur Tengah. Rata-rata pertumbuhan ekspor perikanan tangkap mencapai 23 persen dalam lima tahun terakhir dengan jenis ikan tuna, tongkol dan cakalang. Selain itu, pertumbuhan produksi ikan budidaya seperti kerapu, bandeng, lobster, mutiara dan rumput laut mencapai 25 persen dalam lima tahun terakhir (2012-2017). Semua potensi ini menjadi salah satu peluang untuk menarik minat investor menanamkan modal di bidang kemaritiman di daerah ini.

\section{Proses Konstruksi FRP}

Proses pembuatan kapal fiberglass yang banyak dibuat, menggunakan teknik Fiberglass Reinforced Plastic (FRP). Proses FRP ini sangat berbeda dengan proses pembangunan kapal berbahan material lainnya seperti baja, aluminium, dan kayu. Proses produksi kapal FRP ini jauh lebih ringan dibanding kapal baja. Ini dikarenakan pembangunan kapal konstruksi FRP dimulai dengan persiapan pembuatan cetakan (mold). Sementara proses produksi kapal baja terdiri proses pengelasan, assembly, cutting dan bending. Kapal FRP hanya dibuat dengan modal awal sebuah cetakan untuk membentuk kapal tersebut. Pembuatan mold biasanya menggunakan material FRP yang memiliki ketebalan dan kekuatan tarik tertentu, seperti menggunakan CSM 600 atau juga dapat dibuat dengan kayu dan triplek. Teknologi perancangan FRP terdiri tahap perancangan, pemilihan bahan, dan perhitungan kekuatan (konstruksi). Perancangan FRP ini juga harus memperhatikan kriteria dasar perancangan seperti koefisien pembagian/penggunaan ruang, faktor kenyamanan (safety) dan penampilan (performance). Kapal fiberglass ini efektif untuk meningkatkan produktivitas hasil tangkapan nelayan dan menekan pengeluaran (cost) penangkapan ikan. Umur pakainya lebih lama, kekuatannya tinggi, tahan korosi, ringan, biaya produksi serta maintenance jauh lebih murah dibanding kapal kayu, tidak memerlukan pengecatan yang berulang-ulang. Dalam pembangunan kapal konstruksi FRP, terdapat elemen material utama. $\mathrm{Di}$ antaranya reinforcement, resin, dan core material. Reinforcement atau penguat yang banyak digunakan yakni FRP. Ini dikarenakan biayanya lebih murah dibanding penguat yang 
lain. Resin adalah salah satu bahan dasar yang digunakan dalam industri pembuatan kapal konstruksi FRP. Katalis adalah material yang memiliki fungsi yang sama dengan hardener yaitu untuk mempercepat reaksi proses polimerisasi, namun digunakan sebagai pasangan polyester resin dan vynil ester resin. Gelcoat adalah material yang digunakan sebagai lapisan terluar dari lambung kapal yang akan dibangun.

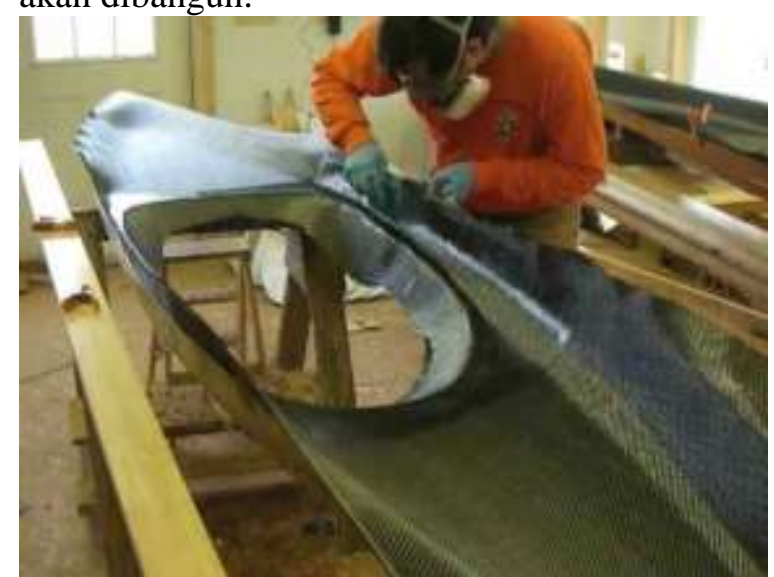

Gambar 1. Konstruksi kapal fiberglass dengan metode FRP

\section{Metode Laminasi}

Dalam pembuatan kapal fiber, terdapat tiga metode laminasi yang sering digunakan. Berikut penjelasan tentang metode laminasi:

1) Metode Hand Lay Up

Metode dasar dalam pembangunan kapal fiber.Metode ini adalah metode laminasi yang paling mudah dan sederhana. Kekurangan metode ini; tidak maksimalnya hasil penyatuan dari lapisan atau susunan antara fiber dan resin pada badan kapal yang terbentuk.

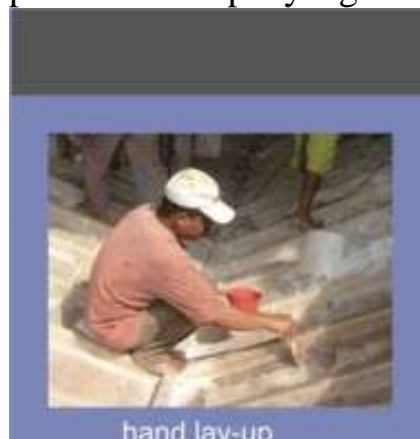

hand lay-up

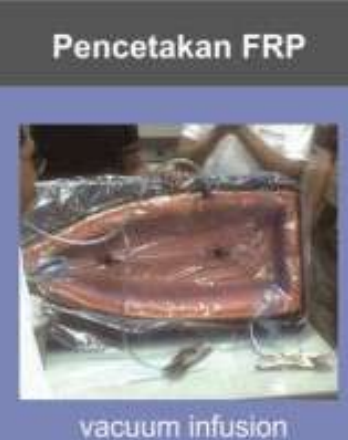

vacuum infusion
Gambar 2. Pencetakan kapal fiberglass dengan perbandingan tiga metode
2) Metode Chopper Gun

Metode ini membutuhkan alat yang berbentuk pistol yang akan menembakkan potongan fiber dengan resin ke seluruh lapisan cetakan (mold) yang kemudian disatukan dengan roll. Pada pelapisan menggunakan teknik chopper gun, hanya dapat menggunakan fiber dalam bentuk gulungan benang (Spray Gun Roving).

3) Metode Vacuum Infusion

Metode ini salah satu metode pencetakan tertutup atau sistem Resin Transfer Moulding (RTM). Resin disuntikkan ke dalam suatu cetakan tertentu, kemudian bagian atasnya ditutup cetakan yang kaku. Namun pada vacuum infusion, cetakan atas diganti dengan plastik film.Keuntungan yang dimiliki metode vacuum infusion; hasil laminasi yang lebih tipis, merata, dan lebih kuat.Penelitian ini, hanya membahas pembuatan kapal dengan pola cetak vacuum infusion.

\section{METODE PENELITIAN}

Metode yang disusun secara struktural dan sistematis akan menghasilkan output yang sesuai dengan tujuannya. Secara garis besar tahapan penelitian ini terdiri tahap perancangan dan pembuatan resin.

2.1 Tahap Perancangan

1. Blender, digunakan dalam proses pencampuran gelcoat dan pigment, pencampuran resin dan bahan-bahan additive (catalyst, accelerator, inhibitor).

2. Kuas/brush, digunakan untuk proses pengecoran resin dan fiberglass secara hand lay out.

3. Roller, digunakan untuk memisahkan udara yang terjebak dalam proses pengecoran FRP.

4. Gunting, digunakan untuk memotong lembaran fiberglass.

5. Power sender, digunakan untuk meratakan atau memperhalus permukaan fiberglass.

6. Mesin bor (drill), digunakan untuk pemasangan perlengkapan kapal.

7. Mesin gerinda, digunakan untuk memotong atau merapikan FRP.

8. Spray gun, digunakan untuk melaksanakan proses penyemprotan gelcoat pada cetakan.

9. Gergaji, clamp, kape, kompresor 


\section{Pembuatan resin}

Biasa disebut polyester resin yakni jenis bahan padat atau semi padat dari alam maupun sintetis, umumnya dengan berat molekul yang tinggi. Resin merupakan salah satu komponen utama pembuatan FRP, sebagai bahan perekat dan pelarut lembaran fiberglass. Bahan penguat (reinforcement) tergantung jumlah, tipe dan susunan fiberglass pada bahan tersebut.Semakin banyak fiberglass, semakin kuat produk tersebut.Berbagai macam fiberglass memiliki komposisi dan spesifikasi.

\section{HASIL DAN PEMBAHASAN Perancangan}

Untuk proses perancangan dibutuhkan variabel panjang total (length over all/LOA), panjang garis air (length water line/LWL), lebar maksimum (beam maximum/Bmax), lebar garis air (beam water line), kedalaman lambung/hull (Depth/D), sarat air (draft/d), displacement, kecepatan maksimum (speed max), jenis/fungsi kapal dan jenis bahan.

\section{Tahap konstruksi (pembuatan gambar)}

Terdiri gambar rencana garis (lines plan and off-set table), gambar kurva hidrostatik termasuk perhitungannya, perhitungan berat dan titik berat, perhitungan trim dan stabilitas, gambar konstruksi profil, gambar penampang tengah, gambar instalasi (listrik, pemipaan, kemudi, mesin, navigasi, komunikasi), gambar interior dan gambar detail lainnya. Berdasarkan gambar-gambar tersebut, proses produksi dapat dimulai. Tahap awal, pembuatan cetakan (mould).Cetakan terdiri dua jenis, yakni cetakan semi permanen dan permanen. Cetakan semi permanen biasanya dibuat untuk pesanan dalam jumlah relative sedikit. Sebaliknya, cetakan permanen dibuat untuk pesanan dalam jumlah relative banyak (produksi massal). Untuk pembuatan cetakan permanen ini, terlebih dulu dibuat prototype kapal yang akan dibuat. Cetakan semi permanen dan permanen terdiri female mould method, yakni cetakan yang sisi bagian dalamnya licin dan sisi luarnya kasar.

Adapun tahap pembuatan cetakan semi permanen adalah pembuatan pondasi dudukan cetakan, potongan-potongan (sections), pemasangan penghubung antar section, pemasangan penutupan cetakan, pemasangan lapisan permukaan cetakan dan finishing. Sedangkan tahap pembuatan cetakan permanen adalah pembuatan pembuatan prototype kapal FRP dari cetakan semi permanen. Setelah tahap pembuatan cetakan selesai, proses produksi dapat dimulai. Untuk menentukan konstruksi dan kekuatan struktur kapal FRP dapat digunakan peraturan seperti Lloyd Register of Shipping 78 (Inggris). Penentuan tebal lapisan struktur kapal FRP dapat ditentukan berdasar kecepatan kapal dan panjang garis alir. Penulangan dan sekat-sekat (girder, frames and bulkhead) dapat digunakan marine plywood yang kemudian ditutup/dicor dengan lapisan fiberglass sehingga merupakan satu kesatuan dengan lambung kapal. Dudukan mesin atau transom kapal outboard engine dapat dipakai double marine plywood yang dilapisi dengan FRP. Sedangkan untuk kapal inboard engine, pondasi mesinnya dapat menggunakan kayu yang kuat dan awet. Jika memungkinkan, digunakan kayu kelas satu serta dilapisi FRP dan diikat mati pada lambung kapal. Penggabungan lambung, dek, anjungan dan sebagainya diikat dengan bautbaut tahan karat (stainless steel) dan di bagian dalamnya didempul serta dicor dengan FRP sehingga tidak bocor.

\section{Tahap finishing}

Adalah untuk meningkatkan tensile dan flexural strength, rasio kekuatan terhadap berat, impact strength, ketahanan terhadap pengaruh suhu, menjaga atau mempertahankan kestabilan bentuk dan memungkinkan dipakai untuk struktur atau kerangka. Bahan additive adalah suatu bahan yang dicampurkan ke dalam resin dan bahan penguat fiberglass dan berfungsi untuk membantu proses pembentukan FRP. Jenis bahan additive antara lain:

a. Catalyst yakni bahan untuk memulai reaksi kimia sekaligus berfungsi sebagai pengering

b. Accelerator yakni bahan untuk mengaktifkan catalyst sehingga terjadi curing lebih cepat pada temperature kamar

c. Inhibitor yakni bahan yang ditambahkan ke resin untuk memperlambat curing.

Bahan ini juga memperlambat polymerase sehingga bisa memperpanjang umur dari monomer/resin. Gelcoat adalah bahan yang berfungsi sebagai lapisan luar dari FRP. Pigment adalah bahan pewarna yang pemakaiannya dicampurkan gelcoat. Kayu, kayu-kayu yang dipakai adalah tahan terhadap
146
Fakultas Teknik UMSB
ISSN 2599-2081
EISSN 2599-2090 
air dan perubahan cuaca (marine wood). Logam, logam yang dipakai mempunyai sifat tahan korosi dan air laut.

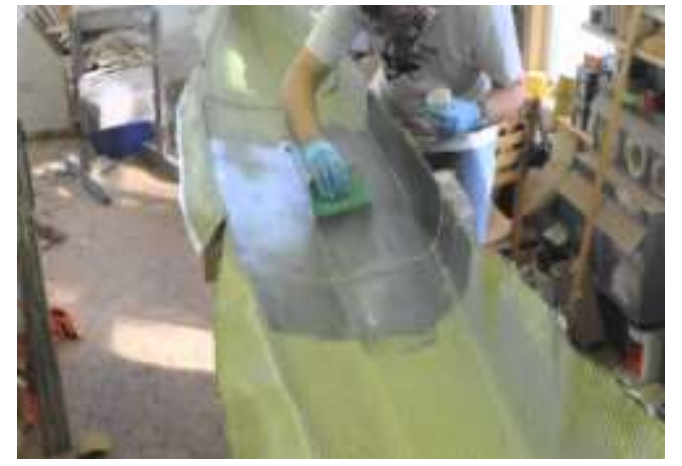

Gambar 3. Tahap finishing dengan metode hand lay up

\section{SIMPULAN}

FRP adalah material terdiri resin, bahan penguat berupa serat gelas (fiberglass) dan additive. Bahan penguat fiberglass maupun proses pencetakan FRP ada berbagai macam, tergantung pada bentuak yang akan dibuat dan spesifikasi yang diinginkan. Keuntungan pemakaian FRP :

a. Kekuatannya tinggi, FRP mempunyai ratio kekuatan terhadap berat yang tinggi, flexural strength dan impact strength FRP umumnya sama, bahkan lebih kuat dari logam.

b. Tahan korosi dan bahan kimia, sifat ini menyebabkan FRP menjadi bahan yang cocok untuk air laut.

c. Ringan, FRP mempunyai kekuatan yang tinggi, namun tetap ringan dibanding logam.

d. Bentuk stabil, bentuk FRP yang telah curing sempurna, tak akan berubah lebih besar dari toleransinya. Semakin tinggi kandungan fiberglass atau kombinasi fiberglass dengan inorganic filler, maka koefisien muai panas dan kontraksi akan semakin berkurang, sehingga bentuk benda tetap terjaga.

e. Mengurangi biaya peralatan, FRP dapat dibuat secara efisien dengan berbagai cara, baik untuk produksi besar-besaran maupun terbatas. Peralatan untuk pembuatan produk FRP lebih murah dibanding peralatan untuk pembuatan produk jenis yang sama terbuat dari logam. Hal ini membuat FRP menguntungkan, baik untuk industri besar ataupun kecil. f. Fleksibel dalam perancangan, FRP dapat dipakai untuk berbagai jenis penggunaan.

g. Dapat langsung dicetak berwarna sehingga produk akhir tidak memerlukan pengecatan lagi.

\section{UCAPAN TERIMA KASIH}

Penulis mengucapkan terimakasih kepada rekan-rekan di Program Studi Teknik Mesin Universitas Dharma Andalas dan Universitas Andalas, sejumlah asisten Labor Metalurgi Jurusan Teknik Mesin Unand, Dinas Kelautan dan Perikanan Sumbar, Dinas Kelautan dan Perikanan Kota Padang dan pihak-pihak yang telah membantu penelitian ini.

\section{DAFTAR PUSTAKA}

D Aditya Amor Patria, Triwilaswandio, Wuruk Pribadi, 2017. Analisis Teknis dan Ekonomis Pembangunan Kapal Ikan Tradisional Ukuran <10 GT Berbahan Kayu Utuh Dengan Teknologi Laminasi Kayu Mahoni, Jurnal Teknik ITS Vol. 6, No. 1.

D Ardiana, R Razali, M Muharnis, 2014. Proses Pembuatan Kapal FRP Berkapasitas 14 M Bagi Nelayan di Kabupaten Bengkalis, Inovtek Polbeng.

Anwar Khaerul, 2012. Analisis Produksi Kapal

Perikanan Berbahan Dasar Kayu dan Fiberglass IPB, Bogor.

Buana Ma'ruf, 2011. Studi Standarisasi Konstruksi Laminasi Lambung Kapal Fiberglass, Jurnal Standarisasi. Vol.13 No.1 p. 16-25.

Munasir, 2011. Studi Pengaruh Orientasi Serat Fiber Glass Searah dan Dua Arah Single Layer terhadap Kekuatan Tarik Bahan Komposit Polypropylene, Jurnal Penelitian Fisika dan Aplikasinya (JPFA), Vol. 1 No. 1 , June.

SA Muharam, 2011. Desain dan Konstruksi Kapal Pibreglass di PT. Carita Boat Indonesia Kecamatan Setu, Kota Tangerang Selatan, Banten, IPB, Bogor.

Parlindungan Manik, Eko Sasmito Hadi, 2008. Analisa Teknis dan Ekonomis Penggunaan Coremat Untuk Konstruksi FRP (fiberglass reinforced plastic) Sandwich Pada Badan Kapal, Jurnal KAPAL, Vol. 5, No.2. 